\title{
Praktická teologie a církevní sociální práce
}

\author{
Karl Rahner
}

(Neautorizovaný překlad z: Karl Rahner: Praktische Theologie und kirchliche Sozialarbeit, Schriften zur Theologie, Bd. VIII, s. 667 - 688, pưvodně vyšlo In: Caritas : Monatsschrift des Schweizerischen Caritasverbandes 45 (1967), s. 354-365)

Pokud mám promluvit na toło téma, které mi bylo dáno', mohu si v nejlepším prípadě připadat jako Bileamův osel, který mluvil prorocky a přsto zưstal oslem. Nejsem sociální vědec ani odborník praktické teologie, tím spiše žádný praktik církevní nebo dokonce profánní sociální práce. Jestliže má snad také těmto věcem trochu rozumět dogmatický teolog, protože z centrálního teologického hlediska musí býł vzat v úvahu křestan i církev také v jejich vztahu ke světu a k pozemskému bytí /Daseins/ člověka, tedy konkrétní dnešní dogmatik musí udělat znovu chybu, a to bud' z poloviny nebo skoro úplně, nebof často citovaná „teologie pozemských skutečností" je i přes pastorální konstituci „O církvi v dnešním světě" ještě zcela v prvopočátcích. Nemohu tuto situaci utajit a říkám s odvahou beznaděje to, co mohu rí́ci². Jestliže se to celé nehodí, nebo znamená př́liš málo, pak musím také apelovat na shovívavost a odpuštění čtenárư a mohu jen doufat, že alespoň rozpor, který je ohlášen, povede možná k jiným pohledům, které jsou lepší než ty zde přednášené. Pokusíme se naše úvahy formulovat ve čłyřech hlavních větách a myšlenkových pochodech.

I.

První základní věta je „vědecko-teoretická“, že totiž učení o křest'anské charitěa církevní sociální práci je vnitřní součástí pastorální teologie, kterou by bylo lépe nazývat „praktickou teologií". Takzvanou "pastorální teologii“ není možné dnes chápat jako uvedení do pastorační práce kléru resp. učení o něm. Pastorální teologie je mnohem více teologickou reflexí celé seberealizace církve vůbec, tak jak je ve své podstatě, $a$ teologickým promýšlením současné situace světa a církve jak dnes má být. $\mathrm{K}$ tomuto celkovému uskutečnění církve ale patří jako aktivní činitelé

\footnotetext{
${ }^{1} \mathrm{~K}$ přednášce srov.. na konci svazku přiložený podrobný seznam pramenů.

2 Autor musí proto odkázat na obsáhlé vlastní předchozí práce, srov. Ausführungen im Handbuch der Pastoraltheologie, hrsg. von F.X. Arnold, K. Rahner u.a., Bd. I-II/1-2 (Freiburg 1964-1966), uvádějící souvislosti svět-církev, situaci dnešní církve a pod. Pro důkladné zdůvodnění je třeba zvláště odkázat na toto dílo (tam viz další obsáhlé údaje o literatuře). - K současnému tématu srov. zvláště také výklad R. Völkl: I, 385-412; II/2, 403 až 423; jinou př́pravu k těmto výkladům nabízí s jiným cílovým zaměřením K. Rahner/K. Lehmann: II/2, 389-402 (Lit.). Srov. také A. Ziegler, Thesen zum Verhältnis von Sozialarbeit und Theologie (Caritas-Verlag Luzern, Sonderdruck); A. Hunziker, Geistige und berufsethische Aspekte der Sozialarbeit: Caritas 45 (1967) (Heft 3 Beilage) 102-116. Pro krátké představení proměny sociální práce, existenciální péče (Daseinsfürsorge) a role dnešní církve může být také upozorněno na tyto práce, srov. K. Rahner, Zur theologischen Problematik einer „Pastoralkonstitution“; Die praktische Theologie im Ganzen der theologischen Disziplinen; Christlicher Humanismus; Die Gegenwart des Herrn in der christlichen Kultgemeinde; Über die Gegenwart Christi in der Diasporagemeinde nach der Lehre des Zweiten Vatikanischen Konzils; Theologische Reflexionen zur Säkularisation, in diesem Band 613-636; 133-149; 239-259; 395-408; 409-425; 637-666. K tématickému okruhu předložené stati srov. také ještě K. Rahner, Der Christ in seiner Umwelt: Schriften zur Theologie VII (Einsiedeln 1966) 91-102.
} 
všechny stupně církevní hierarchie $a$ laici a vše, co v tomto sebeuskutečnění je zahrnuto: nejen kult, učení a pastorace $\mathrm{v}$ užším smyslu bezprostředního zprostředkování spásy jednotlivci, nýbrž právě tak podstatně charita církve a její celé působení v tom, co nazýváme "svět". Tedy k tomu patří také sociální práce církve tím způsobem, s těmi cíli a ohraničeními, jak sociální práce právě církvi jako takové přísluší. K sebeuskutečnění církve se nyní v její stále se měnící situaci dějin světa i spásy nepočítá vše, co křest́an dělá, jelikož se jedná o zcela o „privátní“ prostor jeho bytí. Ale na druhé straně toto sebeuskutečnění není přece identické s výkonem úřadu církve nebo popřípadě laiků, pokud jednají v pověření tohoto úřadu. Patří k němu to, čím se církev (nikoliv ale identická s hierarchii) v rozmanitých způsobech a stupních svého uskutečnění vyznačuje, co ji charakterizuje a v čem se angažuje. Jestliže existuje "privátní“ křest'anské bytí, existuje tedy také privátní, křest'anská, milostí Kristovou nesená mezilidská komunikace a tedy láska, charita v teologickém slova smyslu, která neangažuje církev jako takovou, tak pak přece patří charita a sociální práce do sebeuskutečnění církve jako takové a obě jsou proto předmětem praktické teologie. Je tedy obtížné konkrétně vůči sobě vymezovat církevní charitu a charitu jednotlivce v jeho privátní křest́anské existenci.

Tato první, nyní jen velmi krátce vysvětlená věta, není pouhou teologickou vědecko-teoretickou subtilností a hřičkou. Na jedné straně má teologické přemýšlení o církevní charitě a sociální práci církve, nehledě na praktickou samostatnost vědy o charitě /Charitaswissenschaft/, své podstatné místo $\mathrm{v}$ praktické teologii - a není to jenom nějaká dosud neumístěná libovolná teorie o něčem, co je náhodou v její svatyni, v církevním prostoru, před jejími hradbami; na druhé straně praktická teologie nevytahuje jen konkrétnější důsledky pro činnost pouze církve $\mathrm{z}$,podstatné" eklesiologie, nýbrž tvoří podstatnou, vlastní samostatnou vědu, nebot' ona může z teologicky reflektované analýzy současnosti říci, co církev může nyní - a nikoliv vždy udělat, a protože to může říci s určitým profetickým imperativem. $Z$ toho je zřejmé, že věda o charitě / Charitaswisenschaft) nejen může popsat co vždy charita církve ve vlastním bytí církve znamená, ale musí říci co charita církve musí být právě dnes - nyní a nikoliv v provždy dané ale kriticko-teologicky rozuměné situaci. Věda o charitě má kritickou, takřka prorockou funkci oproti fakticky vykonávané charitě v církvi a musí určitým způsobem se stvořitelskou fantazií z naděje rozvijet stále nové formy charity a vztahu církve ke světu. Ze správně pochopené podstaty praktické teologie vyplývá, že věda o charitě je původně teologickou a kriticko-normativní vědou, která musí obsahovat podstatu sociologie, futurologie a podobných věd - jakožto věd pro ní pomocných. Má vědět, jak má dnes vypadat podoba církevní charity. Není jen souborem praktických rad z podstaty křest́anské lásky, není jen přídavek k morální teologii.

Je ale hned třeba - alespoň jako otázku - poznamenat ještě něco jiného pod podmínkou přeměny charity ve vědu o charitě /Caritaswissenschaft/: existuje pastorální konstituce "O církvi v dnešním světě “; existuje instituce sekretariátu pro dialog a (možná) spolupráci církve s „nevěřícími“ (lépe by bylo s nereligiózním humanizmem), existuje mnohem více míst, kde se podobným směrem myslí a jedná. Ale asi neexistuje pro teologické promýšlení toho všeho co přichází v potaz jako učení a praxe ještě žádné jméno. A přece toto zde je, nezvratitelně uchopitelné i když to nemá jméno. Toto bezejmenné bytí patří podstatně k teologii, ale není identické s celou praktickou teologií, která se také zabývá pastorací v užším smyslu. Toto bezejmenné bytí není ani část dogmatické ekleziologie, i když promýšlí vztah k církvi. Toto bezejmenné není ani identické s křest'anskými sociálními vědami i když je s ním př́ibuzné. Tyto vědy promýšlí společenské, hospodářské a podobné skutečnosti - jaký je v nich vztah vlastní profanity s normami přirozeného zákona a evangelia, nikoliv ale vzájemný, aktivní a pasivní vztah církve a světa jako takového. 
„Teologie pozemských skutečností“ není také správné jméno, protože jde o vztah církve a světa, a sice protože se jedná o oné společenské velikosti jako je lidský skutek, nikoliv jako bezprostřední událost stvořitelského činu Božího. "Politická teologie“ - slovo, kterého se znovu chopil J.B. Metz - není také to, co je zde míněno, nebot " politická teologie“ bere v úvahu společenskou relevanci víry a celou vírou pojatou skutečnost. Američané toto bytí (skutečnost) jmenují jednoduše "Church and World“, myslí tím ale vlastně teologickou disciplínu. Tuto skutečnost bychom měli nazvat "teologicko-ekleziologickou kosmologii“" kdyby jméno kosmologie nebylo spojeno s filozofickou disciplínou, která se ostatně postupně bude podobat transcendentální ontologii a antropologii na jedné straně a přírodním vědám a dějinám na straně druhé.

Když chceme splnit naléhavé a důležité přání po pojmenování této anonymní skutečnosti, vyvstává při tom otázka: neměla by se Charitaswissenschaft, stále chápaná jako část a vnitřní moment praktické teologie rozšiřit a přeorganizovat na eklesiologickou kosmologii? Nebylo by to smysluplné, když na jedné straně uvažujeme, že charita dnes je nutně chápána ve změně forem a způsobů své trvající existence; také církevně organizovaná charita nemůže být jednoduše již identifikovaná s "péčí opatrováním /Fürsorge/“ a hranice mezi charitou a celou světovou působností církve v její všeobecnosti a sociální prací ve speciálním smyslu je velmi těžko určit jak teoreticky, tak prakticky - pokud vůbec existují - a když na druhé straně uvažujeme, že tato teologicko-eklesiologická kosmologie ještě hledá svůj základ a domov, není tedy právě toto reálná možnost se tím zabývat? Charita by se neodcizila sama sobě, kdyby se její věda rozšiŕíla do takové "Kosmologie“; charita by se spojila s "nadějí"3 na kterou se právem odkazuje a spolu s ní by tvořila futurologicko-eklesiologickou kosmologii jako část praktické teologie a tak vybudovala dům, ve kterém by, vedle domu víry, našly vlastní domov v teoretické teologii obě tyto teologické ctnosti. Je pak jasné, že tím by pak Caritaswissenschaft a Teologie sociálních úkolů a práce církve našly užší a srozumitelnější vztah. To vše ale bylo míněno jako otázka.

II.

Přejděme ale nyní konečně k těm skutečnostem, kterými je myšlena charita a sama církevní sociální práce, abychom se přiblížili k našemu vlastnímu tématu. Druhá věta tedy zní: rozdíl mezi církví a milostí na straně jedné a "světem, který se stal světským“ na straně druhé, který dnešní teologie začíná vidět a začíná jej chápat jako rozdíl nastolený samotným křest’anstvím, určuje také a znovu vztah mezi milostí jako „caritas“ a církví jako historicko-společenským projevem této církevní charity na straně jedné a charitou která se stala světskou na straně druhé (jako „smýšleni““ /Gesinnung/ a společenská objektivace).

Nedívejme se napřed na charitu a církevní sociální práci a její profánně-světskou obdobu, nýbrž na milost resp. církev a svět všeobecně a v celku. Existuje "svět" nejen jako Boží stvoření, jako „př́ŕroda“, nýbrž jako úkol, čin a jeho objektivace člověka samotného, jako svět člověkem do budoucnosti navržený, udělaný, ke kterému člověk jako sám sebou manipulující patří. Tento svět se odlišuje nejen od milosti a církve, jako "příroda“ se odlišuje od milosti, jakožto od milosti samé v odlišeném rozlišení předpokládaný adresát a podmínka možnosti milosti jakožto sebesdílení Božího; svět se odlišuje od milosti a církve také epochálně. Svět bude v dalším běhu dějin milosti růst sám ve své samostatnosti, dospělosti, profanitě, a vydá se vlastnímu sebevýkonu. Tato epochálně přibývající „světskost" světa není, navzdory také vždy přítomným hříšným nedorozuměním a hříšnému zkreslení, v posledním porozumění

${ }^{3}$ Srov. Karl RAHNER, Zur Theologie der Hoffnung. In: Schriften zur Theologie VIII, 561-579, zde 575nn. 
neštěstím, které postihne neporozuměnou milost a církev, ale zpơsob, jak se milost sama plně vtáhne do stvoření: jako uvolnění a legitimace světa v jeho osobitosti. Přitom je vidět, že tento svět sám o sobě vlastní opět pluralistickou, ano "smyslově žádostivou“ desintegraci a tak musí být lidmi přijímán a tak jej musí lidé vydržet, tedy ve světě jako takovém neexistuje pro něj samotný žádná předem daná nebo nastolená instance, která by jej mohla adekvátně integrovat do nějakého průhledného a manipulovatelného systému. Víra a církev si tedy proto nenárokují touhu v "integralismu“, který je hluboce nekřest’anský, jednoznačně obsahově pozitivně informovat a manipulovat svět $\mathrm{v}$ jeho skutečnosti a dějinách, ony mu předávají mnohem více sebe sama, dospělému svobodnému člověku svěřují jeho rozhodnutí a odpovědnost za utváření světa, který vytváří. Jaký jiný pozitivní význam pro uvolnění světa do jeho světovosti víra, milost a církev přesto mají, není potřeba v tomto okamžiku říkat, nebot' tato otázka se v naší souvislosti brzy znovu vynoří.

Nyní ale vše mezilidské, ve všech svých dimenzích a vrstvách, patří podstatně kčlověku. Toale znamená, poté co právě bylo řečeno: ono mezilidské patří (také) do světa, který je tak milostí a církví uvolněn do vlastní světskosti. Existuje sice také mezilidskost, která je konstituována skrze milost jako takovou a jen skrze ni, právě „caritas“ v teologickém smyslu, ona jednotou mezi lidmi, která je konstituována skrze božské sebesdílení; tato určitá mezilidskost má v církvi onen charakteristický, symbolický, historicko-základněsvátostný /grundsakramentale/ a účinný projev, který zcela odlišuje církev od světa.

Ale jak odpovídá všeobecnému a také epochálnímu vztahu církve a světa, uvolňuje také tato milostivá, v církvi skrze „caritas“ se projevující mezilidskost epochálně rostoucí světskou mezilidskost jakožto její předpoklad, a zapojuje se v ní; zapovídá si sama „integralistickou“ manipulaci této světské mezilidskosti a posílá křest́ana- také právě jako takového - v jeho svéprávnosti do této ve světě zůstávající mezilidskosti, která je oblastí jeho lidské a křest́anské úlohy, a sama mu pokládá pluralistickou a smyslově touženou neintegrovanou světskou mezilidskost s jejími výkony a objektivacemi jako jeho úděl a břímě. Právě tím, že milost a církev přenechávají ve svobodě svět v jeho samostatné skutečnosti a vlastní odpovědnosti k naplňující se budoucnosti i přítomné úloze, vyhýbá se církev nebezpečí, aby se stala komplicem světa („spojení trůnu a oltáře“) v její společenské, často zkamenělé a dokonce hříchem poznamenané instituci. Získává onen odstup, který potřebuje, jestliže má svou vlastní „vtisknutou“ eschatologickou nadějí plnit službu kritiky a otevření světa jeho budoucnosti ve strukturách (světského) života, jak říká sám koncil (LG 35). Z toho vyplývá: světské, světsky zůstávající společenské konání a jeho světské institucionalizování mohou být v sobě a svém epochálním růstu - a sice také skrze vlastní hospodářské a specificky právní řády společenského života, skrze zákony, trestní pravomoc a policii, skrze kulturní tvưrčí činnost v umění a vědě, tedy také skrze sociální práci a její instituce - viděny z hlediska církve a křest́anů nikoliv jako něco, co by mělo být děláno vlastně lépe pouze církví a křestáany jako takovými, v jejich vlastní režii a s explicitně církevním řízením. Sociální práci nepřísluší prozatím žádná větší specificky křest'anská nebo církevní vazba, než ostatním oblastem světského světa, kultury nebo společnosti. Teologie církve se tedy sama také nevyzná v tom, aby teoreticky a adekvátně rozhodovala konkrétně o nutnosti, naléhavosti, konkrétním ztvárnění a vývojových směrech takové práce na vyšší a podařené socializaci člověka, jakkoliv také křest'ané jako jednotlivci ze své víry a ze své "caritas“ jsou povoláni tomu, aby v otevřeném dialogu a dějinném zápase spolupracovali na dějinách této sociální skutečnosti se všemi ostatními lidmi jakožto občané jednoho světa, a jakkoliv také je církev oprávněna a poslána světu, v jeho svobodné svéprávnosti, nabídnout skrze stále platné principy evangelia slovo prorocké „moudrosti“. 


\section{III.}

Přistupujeme ke třetí větě. Církev (v mnohovrstevnatosti tohoto pojmu) dostala úkol plnit charitativní a sociální práci ve světě; tuto práci nelze a priori a navždy materiálně odlišovat od stejné práce a s ní souvisejících necírkevních (světských) institucí; ohraničení, případné překrývání a dvoukolejnost církevní a profánní charitativní a sociální práce je možné připustit jen podle času a místa, přičemž - jak bylo řečeno - neexistuje žádný řídící apriorní plán a také žádná autonomní instance pro ono ohraničení, nýbrž jen "otevřený“ systém, jenž může dosáhnout vždy jen labilní rovnováhy.

Církev má úkol a právo, které jí z podstaty přísluší, konat ve světě charitativní a sociální práci. Říkáme jednoduše „charitativní" a "sociální" práci. V praxi můžeme možná určitým způsobem charitativní a sociální práci rozlišovat, jednoznačný a podstatný rozdíl teologického rázu mezi oběma není možný, dokonce je zakázaný. Nebot' jestliže charita v teologickém smyslu znamená lásku mezi Bohem a člověkem a mezi lidmi mezi sebou, znamená kompletnost a celistvost člověka a tím jeho spásu, jestliže tato láska neznamená jen smýšlení, ale čin, jestliže je láskou která se vtěluje do celosti lidského života (i když eventuelně profánně světsky a současně anonymně) a když lidské bytí není také vůbec myslitelné bez společensky objektivizované lidské vzájemnosti, pak může všechno konání, které je zaměřeno na bytí jaké má být, na spásu a na společensky konkrétní lidskou vzájemnost, být „materiálem“, výrazem a společenskokonkrétní událostí právě té teologické „caritas“ a nic nemůže být a priori z ní vyloučeno. Ano, tato „caritas“ jakožto celistvá podstata křest'anského bytí má stále povinnost a dynamiku hledat své, nyní nově požadované a sobě připisované, podoby vlastního sebeuskutečnění. Proto patří také všechna sociální práce, přičemž stále zůstává jen službou člověku a jeho mezilidskosti, $\mathrm{k}$ výkonům charity a může být dokonce právě dnes naléhavě nabízena skrze to, co se obecně nazývá "charita“.

Pokud již jednoduché poskytnutí stravy hladovějícím může být a zároveň musí být charitou, dílem charity, pak je od počátku nepochopitelné, jak by mohlo jinak být něco ze sociální služby a sociální práce od počátku vyloučeno z charitního díla. Naopak: v každé době se křest'an a církev musí znovu ptát, v čem právě nyní spočívá oněch sedm skutků "tělesného“ a sedm skutků „duchovního“ milosrdenství. Nemůžeme tyto skutky vidět ve starých představách a modelech zaniklých společenských a hospodářských forem a být tak slepí pro to, co by dnes mělo být konáno jako "caritas" , a to také v tom případě, že to možná nikdo nebude "charitativním" nazývat. Navrhnout systematický přehled takových dimenzí charity, která je také společensky inkarnovaná a institučně založená, jejíž díla nejsou nutně „charitativní" v obvyklém smyslu, nemůže být věcí teologa, bylo by to ale otázkou, které se praktická teologie nemůže vyhnout. Říkáme tomu všemu sociální práce, včetně jejích výkonů, děl, institucí, zařazujeme k tomu také charitativní práci („charita“, jak se tomu tradičně rozumí) jako jednu sice dủležitou část, ale nikoliv jako celek „sociální práce“.

Tato diakonie sociální práce je právem i povinností církve. Nebot' ta není jen společenskohistoricky určeným adresátem a světu věnovanou svědkyní pravdy víry a budoucí naděje (s oběma aspekty: das Grundsakrament), nýbrž také je základní svátostí /Grundsakrament/ jednoty v diakonii lásky.

Nositelem takové sociální práce je církev. Pokud vyslovujeme tuto větu, musíme mít před očima, že slovo "církev“ v této větě je mnohovýznamové a mnohovrstevnaté. Církev ve smyslu praktické teologie a věci samé není sice již uskutečněna tam, kde jednotlivý křest'an v přetrvávající „privátnosti“ svého křestáanského bytí „sociálně“ jedná a musí jednat podle jednotlivého, svobodného a zodpovědného utváření svého mezilidského života; církev 
ještě není uskutečněna tam, kde jednotlivý křest́an tuto svou vlastní úlohu realizuje ve spoluzodpovědnosti za svět, ve světě „soukromě“ nebo jako spoluúčastník světské sociální práce, realizuje jako současně milost působící „caritas“ a světskou úlohu dohromady. Přesto je věta, církev má konat sociální práci činem i pomocí institucí, mnohoznačná. Taková sociální práce církve se děje, když papež a biskupové osobně, avšak jako nositelé církevních úřadů, jsou sociálně činní ve světě již také tak, jako například v encyklice "Populorum progressio“; platí to také $\mathrm{v}$ prrípadě, kdy papež a biskupové skrze úředně pověřené křest'any nebo instituce uskutečňují svou hierarchicko-sociální činnost. Sociální práce církve se děje ale také tam, kde společenství místa a oltáře přispívají důležitým způsobem od oltáře skrze skutky a instituce (např. skrze farní charity apod.) k realizaci mezilidské lásky věřícího společenství také pro vytváření zdravých sociálních struktur světské společnosti.

Sociální práce církve se děje také ještě, a nezastupitelně, když se křestáané jako takoví spojují ve svobodné iniciativě do instituce, která na jedné straně vưbec nemusí vycházet z iniciativy církevního úřadu, vůbec nemusí být jednoduše chápána jako exekutivní orgán úřadu v církvi a vlastně nemusí být jako taková činná, a na druhé straně přece když je taková instituce svobodným seskupením křest'anů a tím stojí v církvi, tedy v církvi jako takto stojící viditelná a má alespoň tichý souhlas církevního úřadu v poskytování jejího svobodného charismatu, pak může v každém případě platit za "církevní". Ne vše "církevní" je pozitivním právním zmocněním založeno ze strany církevního úřadu. Konkrétně mohou existovat přirozeně zcela smysluplné smíšené formy církevně-úřední a současně svobodně-charizmatické avšak církevní instituce, jejichž fungování musí být zajištěno smysluplnými, pozitivními právními ustanoveními. V každém případě „církevní“ není identické s „biskupský“ v právním smyslu, protože také svobodné charisma patří do církve jako takové nebo do ní patřit má. Přirozeně přechody od takové svobodné charismaticko-církevní instituce sociální práce k "světské“ instituci zřizené ale pouze nebo hlavně křest'any, která se explicitně odvolává na evangelium, pro kterou se však církev jako taková včetně jejích úřadi̊ nemůže angažovat, jsou plynulé. To nic nemění na základním principu, že "církevní" a "církevně-úřední /kirchenamtlich/“ není identické, ale částečně různé, nebot' sebeuskutečnění církve jako takové - také na rozdíl od křest'anského bytí a života křest'anů - je implicitnější než činnost úřadu a protože církev je základní svátostí přítomnosti Boží milosti ve světě nejen tím, co úřad církve koná v učení, svátostech a úřední diakonii.

A teprve nyní přicházíme $\mathrm{k}$ rozhodující části naší tř̌etí věty. Je ovšem principielně nemožné jednou provždy stanovit pevné, nehybné hranice materiálního rozlišení mezi oblastí světské a církevní sociální práce, ba dokonce jen formulovat formální princip, ze kterého by pak deduktioně a jistě mohly být tyto hranice položeny $\mathrm{v}$ př́islušných situacích, na rozdíl od moudrého uvážlivého rozhodnutí praxe a zásadně na rozdíl od teorie ${ }^{4}$. Takové materiální vymezení hranic - přímo nebo skrze formální princip - je nemožné a současné není nutné. Je nemožné, protože (kromě hříchu) celé tělo může být a mělo by být prostředkem k výkonu a projevu „charitas“ jako milosti - i když v asymptoticky probíhajícím procesu, který nachází svůj konec teprve v Božím království a tak je stále kontrapunktem k vzrůstající "světskosti“ světa. Všechna sociální práce může tedy být prostředkem výkonu "caritas“ církve, kromě případu, kdy samostatnost světa s jeho institucemi a vlastní sociální prací je podstatně nebo prakticky zdưrazňována; ale právě zde (již ve 2. větě formulována výhrada) neplatí žádný princip jednoznačného materiálního stanovení hranice mezi profánní a církevní sociální prací. Takové materiální stanovení hranic je také i ze strany světa a státu neuskutečnitelné. Nebot' všude, kde profánní sociální čin společnosti slouží věčné důstojnosti osoby, její svobodě a osvobození

${ }^{4}$ Srov. Karl RAHNER, Grenzen der Amtskirche: Schriften zur Theologie VI, 499 - 520. 
od odcizení sebe sama, kde umožňuje člověku být sebou samým a vlastní odpovědností tvořit svůj pozemský a věčný osud, kde jej zbavuje jak je to jen možné všeho předpersonálního, aby se mu dostalo toho nejobtížnějšího: jeho samého $\mathrm{v}$ jeho svobodě, všude tam jsou dány společenské skutečnosti, které mohou být tělem lásky a často také jsou, a tak zvláště anonymně mohou patřit $\mathrm{k}$ projevu církve. Kde se tak nestane, tam není žádná sociální práce ani instituce. Zdali toto, co je tak světské, zůstává a v teologickém smyslu musí být jen anonymní "caritas“, je skutečně projevem lásky ze srdce naplněného Božím duchem, to ví jen Bůh, který sám soudí srdce. Ale to platí také o všech historicko-společenských objektivacích "caritas“ skrze církev.

Přitom platí: principielní materiální stanovení hranic není možné. Přirozeně během dějin byly faktické hranice mezi světem a církví stále znovu hledány: na poli manželství, školy, zvláštní svobody kléru, zdanění církevního majetku atd. Stále se objevovalo takové materiální stanovení hranic, principielně deduktivní - přímo materiální nebo nepř́mo formální - a z obou stran, nebo jen z jedné, at' církve nebo profánní společnosti byly konány poklusy o zvláštní, nereflektovanou směs správných (nebo také nesprávných) teoretických principů, které ale samy nepodávají přesvědčivý závěr konkrétního stanovení hranic (ačkoliv se má za to, že ano) $a$ historické vůle a rozhodování ve svobodném uvažování a také v zápase. Ale má se zato, že se ve skutečnosti realizují jen neměnné principy. Ve skutečnosti je toto stanovování hranic, jakkoliv musí respektovat jisté všeobecné principy (srv. 2. a 3. větu), věcí úvahy, svobodné úmluvy jedné $\mathrm{z}$ obou stran, historické moci $\mathrm{v}$ měnící se situaci, tvưrčí fantazie a dokonce zápasu; je to věcí právě vždy jedinečné, vždy překvapující historie, která se nenechá adekvátně vyjádřit $\mathrm{v}$ teorii, nýbrž je praxí, která je více než časově podmíněným výkonem teoretických principů a plánování. Pokud to uznáme a přitom ze strany církve vezmeme vážně explicitní 2. větu, vynikne důležité ulehčení $\mathrm{v}$ těžkostech církevních rozhodování $\mathrm{v}$ otázce jakou sociální práci má církev nyní konat. To se uskutečňuje dvěma způsoby. Na jedné straně může církev nenuceně, do určité míry „,bez principư“ přenechat mnoho sociální práce kterou někdy dělala narůstajícímu profánnímu světu, který ji sám dělat chce; nemusí si hned dělat starosti, že se vzdává něčeho, o čem se domnívala, že má dělat stále. Předává to tedy jen světu, který, když sociální věci dělá správně, stále ještě vytvář́ objektivace anonymní milosti, na kterých křestáané jako takoví, i když nikoliv „církevně“, mohou a mají spolupracovat, přičemž nesmějí považovat "křest'anské" a "církevní" za identické veličiny; na druhé straně se církev nepotřebuje při přebírání nové sociální práce - právě tak "bez principů“ - stavět před otázku, zda tato nová práce jí podle jejích „principü“ (odhlížeje od principu marnotratné lásky, který již není „principem“) nutně je či není uložena. Církev může rozvinout s větší reflexí svobodnou neomezovanou iniciativu, nechat průchod tvůrčí fantazii a odvaze lásky, vidět úkoly s bdělýma očima a uchopit je širokým srdcem, úkoly, které jinak nikdo nevidí a neujímá s jich. Principiální pevné stanovení hranic také není nutné. Vždyt' stát svobodné pluralistické společnosti musí ze svého bytí chtít, aby "to samé“ bylo vykonáváno jeho jednotlivými skupinami a ve volné soutěži věnováno celé společnosti, která není $\mathrm{z}$ jednoho bodu totalitně ř́zeným uzavřeným systémem, nýbrž „systémem“ stále znovu získávané rovnováhy sil. K tomu je třeba dodat, že zde je místo principu subsidiarity, i když ten jako princip pro položení hranic v naší otázce není vhodný: stát jako takový má, aniž by proto byl „hlídačem“ pouhého práva, sám zř́ídit právě jen ta díla sociálních institucí, která jednotlivé svobodné skupiny společnosti nemohou vykonávat, i když dílo „,sociálního státu“ neboli státu poskytujícího sociální zabezpečení musí dnes být rozsáhlé. Pamatujeme-li na to a počítáme s tím, a to na obou stranách, že svobodné skupiny a tedy i církev budou stále tím více vhodnými poskytovateli sociální práce, čím více se pohybují $\mathrm{v}$ oblasti nepř́lišs právně organizovaných a tedy vynutitelných věcných výkonů, nýbrž pracují-li více způsobem nekomplikované, rychlé, spontánní a "personální" pomoci (což ovšem nevylučuje institucionalizaci), pak nepotřebuje tento "otevřený“ mobilní systém dělby práce $\mathrm{v}$ otázce konkrétního dělení úloh mezi církevní a profánní sociální prací 
vyvolávat neřešitelné konflikty. Vůle ke konkrétnímu řešení může být na obou stranách, když na jedné straně stát nechce být totalitární a církev se na druhé straně nedomnívá, že vzrůstající profánnost světa / ein Wachstum der weltlichen Welt/ je již podstatným ohrožením její vlastní skutečnosti; musí mnohem více nepředpojatě přijímat svou sociologickou existenci v pluralistické společnosti a své věřící do tohoto světa posílat jako upřímné spolupracovníky, aby tam plnili svou křest́anskou úlohu bez integralistických postranních myšlenek.

\section{IV.}

S tím, co bylo řečeno ve 3. větě není popíráno a nesmí být zatemněno, že existuje sociální pomoc, která může být konána legitimně a plně pouze církví a křest'any. Čtvrtá věta by byla v rozporu s předchozí větou v každém případě pouze tehdy, když by se církevní sociální práce mohla nebo směla ohraničit na to, čeho je sama schopna. Abychom pochopili odůvodnění 4. věty, která může být pochopitelná přirozeně jen podle křest'anského pravdivého svědomí, je třeba zvážit více věcí.

Člověk je navzdory a současně v zůstávající pluralitě svých dimenzí, svých zdrojů, svých poznání, motivů a své propojenosti ve společnosti jeden, takže každá dimenze se nachází ve vzájemné interakci s každou jinou dimenzí, žádná není úplně nezávislá, žádná tedy nemůže být zcela uzdravena, aniž by byly uzdraveny ostatní. Jeden z člověkem chápaných momentů z ne zcela ovladatelné plurality lidských (vnitřních a vnějších) dimenzí člověka říká ale také, že každá dimenze má svou vlastní zákonitost a vlastní dynamiku a proto ne každé narušení v jedné dimenzi působí jako zásadní empirické narušení stejné velikosti v dimenzi jiné. Reálně daná jednota pluralitních dimenzí přesto ale působí, že zásadní narušení v jedné dimenzi se přece právě může objevit jako rušící faktor dimenze jiné. $Z$ toho ale vyplývá, že existují narušení jedné dimenze, která jsou odstranitelná jen odstraněním narušení v jiné dimenzi, ačkoliv při zůstávajícím rozdílu mezi oběma dimenzemi může existovat oprávněné úsilí a také určitá šance na úspěch nápravy narušení v jedné určité dimenzi s jejími vlastními prostředky - téměř jako "terapie symptomu“, aniž by se tím předem sledovala náprava vlastní první narušující příčiny v nějaké jiné dimenzi. Tím se ovšem nepopírá, že ten samý symptom může být výsledkem setkání více přičin narušení $\mathrm{v}$ různých dimenzích, a může existovat vzájemná podmíněnost a vyostření mezi narušeními v různých dimenzích; do přičinného kruhu určitým způsobem „uzavřeného“ systému, ve kterém vše závisí od každého momentu systému, nastoupí „efekty zpětné vazby".

Obrat'me na náš případ to co bylo dosud řečeno abstraktně, co nutně vyplývá z nepřekonatelné dialektické jednoty, z jednoty a plurality člověka a jeho světa. Existují narušení, nebo jsou taková alespoň zásadně myslitelná - také v sociální oblasti -, která mohou být odstraněna jen napravením nebo zmenšením narušení v dimenzi religiozity, víry, naděje a lásky v přísně teologickém smyslu slova. Skrze "efekt zpětné vazby“ (a také od něj odhlížeje) má „terapie symptomů" v každém případě své oprávnění a také šance, právě tak jako na příklad je možné pomocí léků na spaní odstranit nespavost, nebo alespoň se o to pokusit, i když tato nespavost pochází z nezpracované viny. Ale to nic nemění na věci, že sociální konflikty - jak více individuální tak i kolektivní povahy - mohou existovat a také existují, jako - i když ne jen následky narušení náboženských vztahů mezi člověkem a Bohem a (kvůli jednotě lásky k Bohu a bližnímu) náboženských vztahů mezilidské povahy. Toto "teologické“ základní narušení může spočívat jak v původním základním vztahu člověka k Bohu a k bližním, tak také v pojmové a tedy kultické, sociální objektivaci církevní povahy, což není totéž, ale obojí může vzdáleně působit v ostatních oblastech lidského bytí a tedy také právě v sociální dimenzi a v zásadě také působí, přestože nikoliv nutně a vždy v empiricky (,klinicky“) závažné míře. 
Ve skutečnosti: kdo neprožívá poslední soulad s nejhlubším neuchopitelným tajemstvím bytí, které se nazývá Bůh, ve víře, naději a lásce, nemůže také tak přijímat a vydržet tak jak je to nutné mezilidskost a její konkrétní sociální situace, se vší její tvrdostí, zklamáním, stále novými úkoly, odpovědností a její společensko-historickou konkretizací. Těsnost mezilidskosti ve všech jejích aspektech s celou délkou a šiří prostorové a časové povahy lze vydržet jen v šíři svobody dětí Božích. Často se může stát, že se toto přihodí někomu v „anonymním“ křest'anství, a my v pravdě netvrdíme, že jen explicitní křest’ané jsou hotovi se svou mezilidskostí "klinicky“ dostatečným způsobem. Ještě méně tvrdíme, že je možné manipulovat tím, co je „náboženské“ jakožto prostředkem $\mathrm{k}$ zvládnutí sociálních konfliktů, aniž by se tím narušila jeho podstata. Bůh je opravdovou životní pomocí právě jen tehdy, když se člověk do něj vnoří, tak jak on je svatý a úctyhodný, a pokud si jej člověk sám činí cílem a smyslem a nikoliv prostředkem pro něco jiného. Ale to vše nemění nic na tom, že sociální konflikty mohou pocházet a pocházejí také z narušeného vztahu k Bohu. Proto má tedy křesteanství a církev vlastní úkol v sociální práci, který nikdo nemůže církvi odebrat. Církev sice nemůže tento vztah člověka a Boha založit, to je věcí samotného každého člověka ve svobodě a milosti, ale církev je přece zprostř̌edkovatelkou tohoto vztahu skrze účinná znamení vlastních slov a svátostí a lásky, která se ve společenství věrících děje a projevuje se navenek.

To tedy samozřejmě znamená, že církev právě také svým specificky náboženským, spásu zprostředkujícím konáním, působí také sociálně. Ale to právě neznamená, že by církev byla omezena na tuto vlastně religiózní oblast sociální působnosti. Zcela naopak, když přihlédneme $\mathrm{k}$ tomu co bylo řečeno ve 3 . větě a dále právě o „efektu zpětné vazby“ různých dimenzích člověka, pak se ukazuje následující: oblast sociální práce církve leží na jedné straně tam, kde se dotýká vlastního náboženského problému a tak plní specificky církevní a misionářskou úlohu a na druhé straně ve specificky sociálních konfliktních situacích, které - alespoň částečně jsou následkem a současně posilněním náboženského konfliktu $a$ současně tvoří situaci, ve které náboženský problém člověku většinou teprve přichází na vědomí a stává se předmětem reflektovaného rozhodování. Jinak řečeno: ono vykonávané nebo očekávané dílo lásky a nedostatek takového díla, které samotné dlouhodobě bez věrící a doufající lásky nemůže být děláno, je situací, ze které člověku může vzejít konkrétní náboženská otázka, a místem sociální práce, která je pro církev specifickou. To je také ještě řečeno velmi abstraktně, a nemůže to nahradit tvưrčí fantazii, která může takové situace objevit. Aleje to přece tak: „čistě“ náboženská samotná pastorace kázáním a svátostnou bohoslužbou je určitým způsobem př́liš abstraktní. Samotná tato pastorace není tam - nebo není postačující tam, kde stojí člověk v sociálním konfliktu, který má náboženské pozadí a náboženskou hloubku, jež v konkrétním případě sociálního konfliktu je lépe patrné než v nějaké „abstraktní" situaci, ve které se děje a církevně zprostředkovává ono „čistě náboženské“. Takový konflikt již proto, že nemá konkrétní čistě náboženský původ a protože existuje oprávněná "terapie symptomů“ - nepotřebuje materiálně jednoznačné ohraničení od předmětů profánní sociální práce a pomoci; přece je v podstatě „případem“ specifické církevní sociální práce.

Z řečeného vlastně také již musí být zřejmé, že na jedné straně poskytovatel takové církevní sociální pomoci nemusí být nutně vysvěcený kněz, který proto většinou není a nemá být dostatečně vzdělán a že na druhé straně laický církevní „,sociální pracovník“ odtud sám získává podstatu a úkol náboženské a církevní relevance, která dosud přece ještě není dostatečně zřetelně viděna. Problém církevních sociálních pracovníků by mohl být viděn v novém světle v př́ipadě vysvěcených jáhnư 5 .

${ }^{5}$ To přirozeně neznamená - právě na základě zde uvedeného - že církevní sociální práce by měla být zase zklerikalizována. K s tím spojenému problému diakonátu srov. K. Rahner/H. Vorgrimler/J. Kramer, Zur 
Dále je tím také ještě řečeno: sociální práce na kterou je nyní církev zaměřena má ze své podstaty jistý velmi „personální" charakter; to ale nutně nevylučuje její podstatě odpovídající trvalou organizaci a institucionalizaci. Když dokonce svátostná životní pomoc, např. ve svátosti smírení vykazuje velmi důležitý moment institucionalizace a "organizace“ , pak to také v našem případě od počátku nemůže být nemožné.

Zvláštním, ale možná dnes velmi důležitým druhem této specificky církevní sociální práce by byla výpomoc při překonání oné sociální desintegrace, která dnes sama vystupuje z nejrůznějších důvodů uvnitř křest'anských místních a oltářních společenství; tento úkol je sice věcí pastorace všeobecně, ale může zde nalézt zcela podstatnou podporu. Jestliže zaprvé křest'anské společenství musí být více než farní záměr pastoračního chápání určité lokálně vymezené skupiny lidí a setkávání se mnoha lidí bez vzájemných vazeb na stejném místě a ve stejném čase $\mathrm{k}$ uspokojení individuálních náboženských potřeb, a jestliže za druhé církevní společenství, které se schází k bohoslužbě již není, jak tomu bylo dříve, také profánně společenskou integrovanou skupinou, a jestliže za třetí samotná tato integrace nemůže být způsobena faktickou bohoslužbou jako takovou, pak je zde již dán úkol pro specificky křest'anskou sociální práci, která sama o sobě dosud není dostatečně zřetelně viděna.

Křest'anské společenství (at' teritoriálně nebo funkčně strukturované) může jako společenství v diaspoře, jako církevní společenství na rozdíl od lidové církve dnes v sobě rozvinout někdy nábožensko-sociologicky skoro "církevně sektářské“ struktury, všechno pak záleží na tom, zda se společenství nezakotví v sektářské mentalitě, nýbrž zda je společenstvím misionářským, nepředpojatým a majícím odvahu účastnit se na celém životě dnešní pluralistické a profánní společnosti. Ale toto společenství nemá nejednou status opravdového církevního společenství, nýbrž se pohybuje v neurčitém meziprostoru mezi starou „lidovou církvi“" , zjejíž sociologických předpokladů jeho členové ještě čerpají, a skutečným církevním společenstvím lidí s upřímným vlastním náboženským rozhodnutím, přičemž toto společenství zde ještě není.

Církevně-sociální integrace společenství samotného, která nemůže být prováděna samotným pouhým „kázáním“ v obvyklém stylu teoretické indoktrinace, je dnes specifickým úkolem sociální práce církve, který nemůže být splněn samotným „duchovenstvem“. Obrazně řečeno: diakonická služba charity konaná jáhny a jáhenkami se dnes nemusí starat jen o to, zda je společenství již shromážděno u "stolu“ (Sk 6,2), zda vše probíhá správně a $\mathrm{v}$ pořádku, nýbrž nejprve o to, aby slabý a nedostatečně integrovaný spolek věřících byl vůbec společenstvím "stolu“.

A dále - neplatí něco takového dnes v době ekumenismu také svým způsobem pro určitou integraci konfesně rozdělených skupin, pro integraci, která předchází a teprve umožňuje touženou jednotu církví v př́ísně teologickém smyslu? Není něco takového také církevně sociální práce, kterou nikdo jiný, než církev, nebo církve nemůže vykonávat? Nemusí být viděna a konána, když církevní rozkol povstal právě nejen z teologických, nýbrž také z - v širším slova smyslu - sociologických př́ičin?

\section{V.}

Vím, že vše, co jsem uměl říci, je a musí být vystaveno nejen kritice a nesouhlasu, což je samozřejmé, nýbrž že to zůstalo tak abstraktní a formální, že se praktik bude ptát: co se s tím dá dělat? Jsem si vědom toho, že jsem mohl jen trochu zodpovědět otázky, které nám dnes 
konkrétně věc sama staví. Ale může odborně i věcně vzdálený teolog udělat více? Možná přece poskytnou tyto formální úvahy něco jako souřadnicový systém, ve kterém opravdoví odborníci z teorie i praxe přece jen trochu snadněji - s laskavostí a dobrou vưlí - mohou nalézt a stanovit polohu toho, c o sami musí hledat a nalézat.

\section{Co jsem chtěl říci,bylo vlastně jen následující:}

Zaprvé: Dnes se může a má nově promyslet teologicko vědecko-teoretický koncept charitní vědy jakožto vnitřní moment praktické teologie, která je sama samostatnou teologickou vědou a nejen jednoduchý „praktický“ přivěšek ostatních teologických disciplín, tak že charitní věda která je pojmenována po „caritas“ by se stala nejvyšší entelechií všeho křest'anského jednání, vědou konkrétní právě nyní nutné světové zodpovědnosti křest'anů, ,"teologickou kosmologii“"; zbavila by se tak také fatálního podezření, že je jen teorií oné péče, která se v sociální společnosti a ve státě který sám sociálním státem je a musí být, stává stále problematičtější, protože církevní péče může nejvýše ještě vykonávat službu pomocníka v nouzi tam, kde profánní společnost v rozporu s očekáváními selhává.

Zadruhé: Ve 2. a 3. větě je pokus ukázat, že koexistence církevní a profánní sociální práce je požadována z podstaty samého křest́anství a problém stanovení hranic mezi oběma není problémem teoretických úvah a apriorních dedukcí, nýbrž problém stále nového, historického rozhodování; v tomto rozhodování se může církev jednak směle zříci starých sociálních funkcí, které někdy měla $a$ směle vidět a uchopit nové úkoly sociální práce ve světě a v profánní společnosti. Tento odkaz problému hranic vyvstalý ze základních úvah určených praktikům, může být pro ně samé nepř́ijemný, protože jim ztěžuje úkol a rozhodování, které by jistě raději přenechali jiným. Ale dochází tím také k osvobození praxe a praktiků: nepotřebují čekat na konkrétní imperativ z velící centrály, která by byla obsazena jen teoretiky kteří sedí na principech; mohou sami rozhodovat v nalézání imperativů, které nejsou jen překladem principů, ale jsou historickými, ano charismatickými rozhodnutími, ve kterých se manifestuje neodvoditelnost praxe vůči teorii a přednost praktického rozumu před teoretickým.

Zatřetí: Navzdory koexistenci a interferenci mezi církevní a profánní sociální prací existuje specifická církevní sociální práce, které dnes přibývá zcela nová úloha jak ve světě, tak v samotné církvi.

Více nemůže být řečeno. Utěšuji se starou větou: „In magnis voluisse sat est", nebot' největší je stále ještě láska. Pokud se o ní mluví a při snaze ji chválit je pak možno prosit o absoluci a doufat v ní. 